\title{
Estimates of Health Care System Costs of Unsafe Abortion In Africa and Latin America
}

\author{
By Michael \\ Vlassoff, Damian \\ Walker, Jessica \\ Shearer, David \\ Newlands and \\ Susheela Singh
}

Michael Vlassoff is senior research associate, and Susheela Singh is vice president for research, both at the Guttmacher Institute, New York. Damian Walker is associate professor, and Jessica Shearer is research associate, both in the Department of International Health, Johns Hopkins

Bloomberg School of Public Health,

Baltimore, MD, USA.

David Newlands is senior lecturer, Department of Economics, Aberdeen University, Aberdeen, Scotland, UK.

CONTEXT: Each year, 19 million unsafe abortions occur in developing countries, and an estimated five million women are treated for the resulting serious medical complications. Meanwhile, the economic impact of postabortion care on health care systems in Africa and Latin America is poorly understood (data for Asia are lacking).

METHODS: Two main approaches were used to estimate the cost of postabortion care: calculating the average cost of care per patient, as represented in 20 empirical studies, and analyzing treatment costs using the WHOMother-Baby Package model, which enumerates the costs of specific components of treatment related to postabortion complications. The average cost estimates from each approach were multiplied by the annual number of cases of hospitalization for postabortion care to generate regional cost estimates. Three methods (low severity, weighted severity, and inclusion of overhead and capital costs) were used to generate a range of per-patient and regional cost estimates.

RESULTS: The average per-patient cost of postabortion care ranged from \$83 in Africa to \$94 in Latin America (2006 US\$); estimates based on the WHO Mother-Baby Package model were between \$57 and \$109 per case. The health system costs of postabortion care in the two regions combined ranged from $\$ 159$ million to $\$ 333$ million per year. The average estimates from the two approaches were similar: $\$ 280$ million and $\$ 274$ million, respectively.

CONCLUSIONS: The costs of treating medical complications from unsafe abortion constitute a significant financial burden on public health care systems in the developing world, and postabortion complications are a significant cause of maternal morbidity.

International Perspectives on Sexual and Reproductive Health, 2009, 35(3):114-121

Each year, an estimated 19 million unsafe abortions occur in the developing world, and around 66,500 women die from abortion-related causes. ${ }^{1}$ In developing countries, an estimated five million women are treated annually for complications from unsafe abortion, ${ }^{2}$ the cost of treating such complications burdens health care systems in these countries, where $97 \%$ of all unsafe abortions occur. ${ }^{1}$ This treatment diverts scarce health resources and, as we will demonstrate, is more costly than the alternatives of safe abortion and contraceptive services. Therefore, quantifying the economic costs of unsafe abortion is critical for informing public policy.

\section{FRAMEWORK FOR ANALYSIS}

Unsafe abortion generates unnecessary costs to society on a variety of levels. A proportion of women who have unsafe abortions will experience complications; some of these women will seek care within the formal health care system, while many will seek care elsewhere or not at all (Figure 1). Where women obtain care determines who bears the direct medical costs. ${ }^{*}$ In public facilities, costs may be shared between households and the government if fees are

*Direct costs are linked to provision or receipt of postabortion care, in cluding costs of supplies, staff time and patient travel, whereas indirect costs represent overhead and capital costs, as well as the value of lost productivity due to illness or disability. charged. The process of seeking care will also incur direct nonmedical costs, such as transport costs, which can be significant. ${ }^{3,4}$

Women suffering from complications face three possible outcomes: survival with no long-term consequences, survival with long-term consequences or death. Each outcome generates indirect costs in the form of lost productivity, which will be borne by the households affected and, more broadly, by society. In economies with large pools of unemployed workers, these costs may be more easily offset at the societal level. That is, to the extent that unemployed persons take over the productive work not done by women who have suffered abortion complications, little or no net loss of productivity may be experienced by society. Indeed, even at the household level, some short-term productivity loss can be made up by the individuals themselves or by friends and family. However, long-term productivity losses cannot be offset at an individual or household level in the same way they can be at the societal level. Moreover, all coping strategies impose costs of one sort or another. Finally, children in households experiencing long-term maternal disability or a maternal death may also suffer in terms of their future health and education attainment, ${ }^{5}$ which has further economic implications for the household and society.

While we recognize the multidimensional nature and 


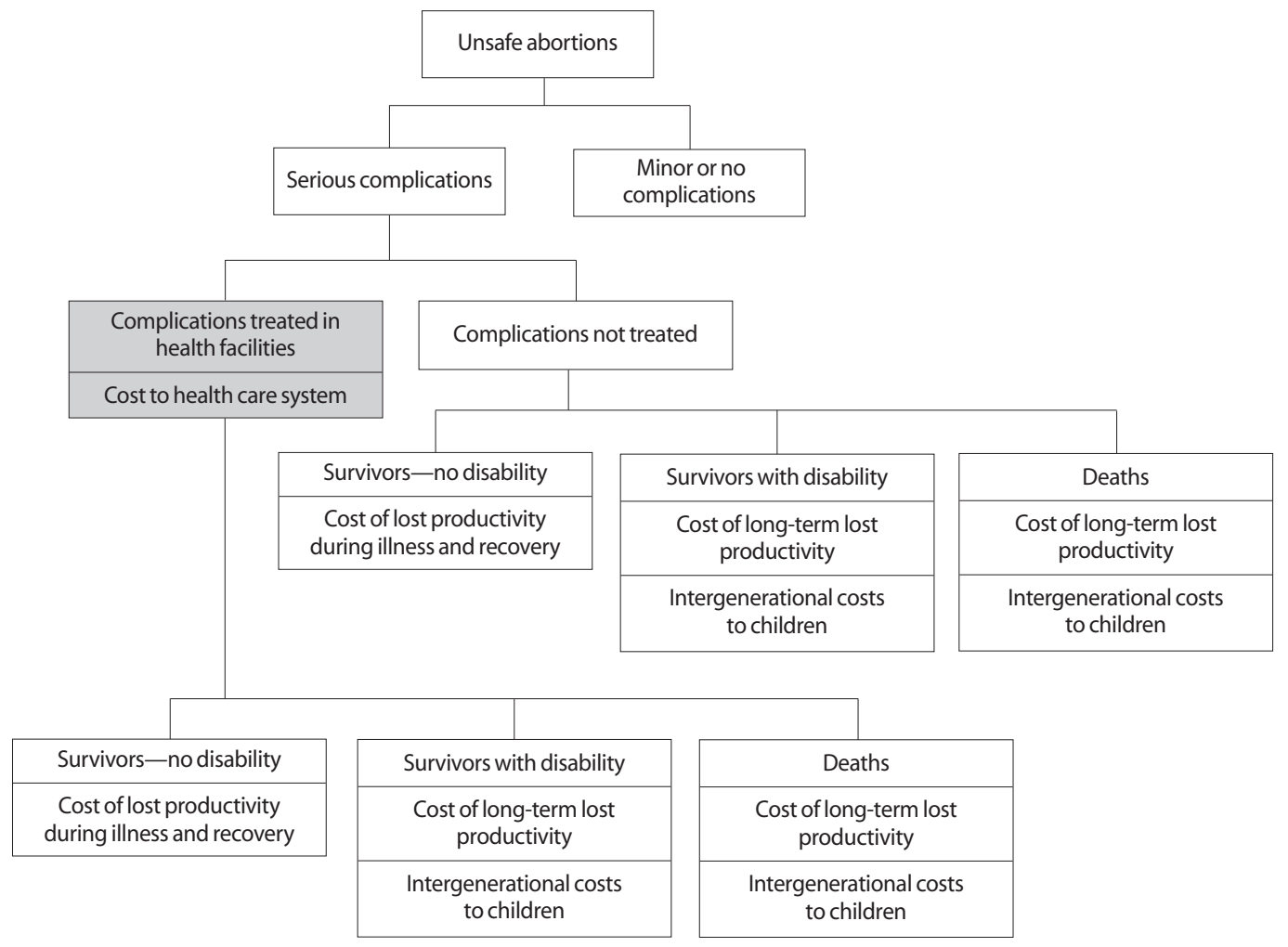

range of potential economic impacts, we focus on estimating one component-the cost of unsafe abortion to the health care system (the lower shaded cell in Figure 1). Household costs are excluded from this analysis, not because they are unimportant, but because of the lack of empirical data. Productivity losses and intergenerational costs are also excluded because of the paucity of empirical studies, as well as the lack of consensus among economists regarding how to value such losses. ${ }^{6}$

\section{METHODS AND DATA}

The evidence base on the cost of unsafe abortion is limited, and regional economic impacts are currently unknown. This analysis addresses existing data constraints by using two different approaches: estimating the average cost of postabortion care per patient based on available literature, and using results from studies that applied the World Health Organization (WHO) Mother-Baby Package costing model. We refer to the first approach as "top down" because it uses empirically derived overall treatment costs per patient, while we refer to the second as "bottom up" because it uses cost estimates of each specific component (e.g., supplies, drugs and labor) needed for treatment of each type of abortion complication to calculate the overall cost.* When multiplied by estimates of the number of women hospitalized for serious medical complications of induced abortion, the two approaches provide a range of estimates of the direct cost of unsafe abortion to health care systems in Africa and Latin America.
(We are not aware of any relevant cost data for Asia.) To reiterate, these cost estimates do not include certain costs borne by households-for example, direct medical costs such as the purchase of drugs or other supplies, the cost of the unsafe abortion procedure, direct nonmedical costs such as transport to facilities, or the costs of lost productivity due to ill health or disability.

\section{Top-Down Approach}

The first approach was based on the average cost of postabortion care as calculated from available empirical studies. Using validated search terms for economic evaluations, ${ }^{7,8}$ namely, "economics" or "cost" and "abortion" or "postabortion care," we conducted a systematic literature review of the Medline, Embase, Econlit and Popline databases. Of the studies yielded by this review, only those published between 1985 and 2007 that described data collected in low- or middle-income countries were selected. We searched the Web sites of relevant organizationsincluding the Population Council, Guttmacher Institute, United Nations, WHO, Pathfinder and Ipas-for project reports, and contacted staff at these organizations for further information. We manually searched relevant journals' tables of contents, as well as conference proceedings related

*The terms "top down" and "bottom up" indicate the analytical direction of each approach. The first approach starts with the total cost per case, whereas the second starts with the costs of all the specific components (the "bottom") that collectively make up a treatment or intervention, and then totals them to derive the total cost per case (the "top"). 
TABLE 1. Average cost of postabortion care per patient, by severity of complications, region and cost estimation method, based on 20 studies including 72 samples

\begin{tabular}{|c|c|c|c|c|}
\hline Category & $\begin{array}{l}\text { No.of } \\
\text { samples/ } \\
\text { studies }\end{array}$ & $\begin{array}{l}\text { US\$ } \\
\text { (study year) }\end{array}$ & $\begin{array}{l}\text { US\$ } \\
(2006)\end{array}$ & $\begin{array}{l}\text { International \$ } \\
\text { (2006) }\end{array}$ \\
\hline \multicolumn{5}{|l|}{ Average of samples } \\
\hline All samples & 72 & $\$ 70.56$ & $\$ 86.04$ & $\$ 176.02$ \\
\hline Low-severity samples & 46 & $\$ 57.43$ & $\$ 72.07$ & $\$ 132.82$ \\
\hline All-severity samples & 26 & $\$ 93.78$ & $\$ 110.76$ & $\$ 252.45$ \\
\hline \multicolumn{5}{|c|}{ Average of within-study averages } \\
\hline All studies & 20 & $\$ 71.09$ & $\$ 88.28$ & $\$ 187.16$ \\
\hline Low-severity studies & 10 & $\$ 54.91$ & $\$ 67.72$ & $\$ 126.88$ \\
\hline All-severity studies & 10 & $\$ 87.26$ & $\$ 108.84$ & $\$ 247.45$ \\
\hline \multicolumn{5}{|l|}{ Region } \\
\hline Africa & 10 & $\$ 62.93$ & $\$ 82.63$ & $\$ 212.87$ \\
\hline Sub-Saharan Africa & 9 & $\$ 67.56$ & $\$ 88.82$ & $\$ 227.92$ \\
\hline Latin America & 11 & $\$ 79.24$ & $\$ 93.92$ & $\$ 161.45$ \\
\hline \multicolumn{5}{|l|}{ Estimate } \\
\hline 1.Lower bound* & 20 & $\$ 54.91$ & $\$ 67.72$ & $\$ 126.88$ \\
\hline 2. Weighted by severity $\dagger$ & 20 & $\$ 93.21$ & $\$ 114.96$ & $\$ 215.38$ \\
\hline \multicolumn{5}{|c|}{ 3.Overhead/capital costs added $\neq$} \\
\hline Africa & 10 & $\$ 87.02$ & $\$ 114.26$ & $\$ 294.35$ \\
\hline Sub-Saharan Africa & 9 & $\$ 93.42$ & $\$ 122.82$ & $\$ 315.16$ \\
\hline Latin America & 11 & $\$ 109.57$ & $\$ 129.87$ & $\$ 223.25$ \\
\hline
\end{tabular}

*Estimate 1 uses the average costs of treating low-severity complications. FEstimate 2 incorporates information on the incidence and cost of treatment by the severity level of complications, and calculates the average cost across all levels of severity. \#Estimate 3 uses data from studies that applied the Mother-Baby Package costing model; to account for overhead and capital costs, observed costs were inflated by a factor of 1.38 .

to maternal, sexual and reproductive health.

One hundred and seventy-two studies were identified and screened, resulting in 20 studies with empirical data. Selected studies had to present original data, analyze costs from a health systems perspective and provide sufficient detail about their methods (i.e., a description of inputs and their quantity, sample size and analytic methods) to allow us to assess study quality. In these 20 studies, 72 samples with distinct cost-per-patient results were presented and analyzed. ${ }^{9-31}$

Reported costs were converted to both 2006 U.S. dollars and 2006 international dollars. ${ }^{* 32}$ Study-year costs in U.S. dollars were adjusted for inflation using U.S. gross domestic product deflators to arrive at the 2006 costs; these were then converted to 2006 local currency costs using official exchange rates and divided by the purchasing power parity conversion factor to arrive at the cost in 2006 international dollars. All historical economic data were taken from the World Bank's World Development Indicator database. ${ }^{33}$

In addition, three cost estimation methods were used to calculate a range of costs for postabortion care. Estimate 1

\footnotetext{
*The international dollar is a hypothetical unit of currency used for comparisons between countries, and it has the equivalent purchasing power of a U.S. dollar in the United States at a given point in time. Although we include international dollars in Table 1, our analysis relies almost exclusively on comparisons of costs in U.S. dollars (2006).

†An earlier report presents a detailed description of the methodology used in our study (source: Vlassoff $\mathrm{M}$ et al., Economic impact of unsafe abortion-related morbidity and mortality:evidence and estimation challenges, Research Report, Brighton, UK: Institute of Development Studies, 2008, No. 59).
}

used the average costs of treating low-severity complications, and hence represents the lower boundary of estimates. Estimate 2 incorporated information on the incidence and cost of treatment by the severity level of complications. For this method, we combined results from two studies that measured the severity of complications using similar methods and that provided information on the percentage distribution of postabortion patients by severity in South Africa and Kenya: ${ }^{22,34}$ Low-severity cases represented $64 \%$ of postabortion care cases, mid-severity cases $16 \%$ and high-severity cases $21 \%$. Using these weights and estimated costs by severity from the South African study, we calculated the average cost across all levels of severity. This approach is crude, and it extrapolates data from two Sub-Saharan African countries to the African and Latin American regions. Nonetheless, it does take into account an important cost driver-the severity pattern of postabortion care.

Finally, because most studies have underestimated the true cost of treatment by omitting hard-to-measure cost components-in particular, overhead and capital costsEstimate 3 used data from five studies that applied the Mother-Baby Package costing model. Direct costs were estimated to be $72 \%$ of total costs, overhead costs $16 \%$ and capital costs $12 \%$. Observed costs were therefore inflated by a factor of $1.38(1.00 / 0.72)$. The estimated postabortion costs using this method are higher than those from the other two methods and so form the upper boundary of the cost ranges.

\section{Bottom-Up Approach}

The second approach to estimating the cost of postabortion care was based on use of the WHO Mother-Baby Package costing spreadsheet. ${ }^{35,36}$ In this approach, treatment for each type of postabortion complication-incomplete abortion, sepsis, shock from blood loss, cervical and vaginal lacerations, and uterine perforations-is broken down into quantities and unit costs of drugs, materials, equipment, personnel, overhead and capital expenditures. The model has been applied in five country studies. ${ }^{9,10,14,15,31}$ These studies estimated costs for all Mother-Baby Package interventions by treatment site (i.e., health center, hospital and overall), except for the Nigerian study, ${ }^{10}$ which focused solely on costs of postabortion care. The Ghana, Bolivia and Uganda studies ${ }^{9,15,31}$ collected cost data on actual practice, and then estimated costs for WHO-recommended standard practice, which represented compliance with WHO-defined protocols for the various interventions. The Mexico study calculated costs only for standard practice. ${ }^{\dagger 14}$

\section{RESULTS \\ Cost per Patient}

The average cost of postabortion care per patient, when based on all samples from the 20 studies, was $\$ 86$ (2006 US\$; Table 1); costs ranged from $\$ 2$ to $\$ 390$ (not shown). Of the 72 samples, 46 were categorized as representing lowseverity complications under the Kay-Rees severity frame- 


\begin{tabular}{|c|c|c|c|c|c|c|c|c|c|}
\hline \multirow[t]{2}{*}{ Study area } & \multirow[t]{2}{*}{$\begin{array}{l}\text { Year of } \\
\text { study }\end{array}$} & \multicolumn{2}{|c|}{$\begin{array}{l}\text { Health centers } \\
\text { (US\$ in study yr.) }\end{array}$} & \multicolumn{2}{|c|}{$\begin{array}{l}\text { Hospitals } \\
\text { (US\$ in study yr.) }\end{array}$} & \multicolumn{2}{|c|}{$\begin{array}{l}\text { Overall } \\
\text { (US\$ in study yr.) }\end{array}$} & \multicolumn{2}{|c|}{$\begin{array}{l}\text { Overall } \\
\text { (2006 US\$) }\end{array}$} \\
\hline & & Actual & $\begin{array}{l}\text { WHO } \\
\text { standard }\end{array}$ & Actual & $\begin{array}{l}\text { WHO } \\
\text { standard }\end{array}$ & Actual & $\begin{array}{l}\text { WHO } \\
\text { standard }\end{array}$ & Actual & $\begin{array}{l}\text { WHO } \\
\text { standard }\end{array}$ \\
\hline Uganda 31 & 1996 & $\$ 1.71$ & $\$ 9.78$ & $\$ 12.16$ & $\$ 34.51$ & $\$ 8.24$ & $\$ 25.24$ & $\$ 10.16$ & $\$ 31.24$ \\
\hline Bolivia15 & 1997 & $\mathrm{u}$ & u & $\mathrm{u}$ & $\mathrm{u}$ & $\$ 69.00$ & $\$ 109.00$ & $\$ 83.67$ & $\$ 132.17$ \\
\hline Mexico $^{14}$ & 2001 & $\mathrm{u}$ & $\$ 94.07$ & $\mathrm{u}$ & $\$ 198.36$ & $\mathrm{u}$ & $\$ 187.42$ & u & $\$ 211.72$ \\
\hline Ghana $^{9}$ & 2003 & $\$ 36.90$ & $\$ 36.09$ & $\$ 54.85$ & $\$ 56.40$ & $\$ 45.88$ & $\$ 46.25$ & $\$ 49.92$ & $\$ 50.33$ \\
\hline Nigeria $^{10}$ & 2005 & $\$ 74.00$ & $\mathrm{u}$ & $\$ 132.00$ & $\mathrm{u}$ & $\$ 103.00$ & $\mathrm{u}$ & $\$ 112.08$ & $\mathrm{u}$ \\
\hline Sub-Saharan Africa & & na & na & na & na & na & na & $\$ 57.39^{*}$ & $\$ 64.55 \dagger$ \\
\hline Latin America & & na & na & na & na & na & na & $\$ 108.85 \ddagger$ & $\$ 171.95 \S$ \\
\hline
\end{tabular}

*Average of Uganda, Ghana and Nigeria. $†$ Average of Uganda, Ghana and Nigeria, assuming that Nigeria's standard cost is the same as its actual cost. $¥$ Average of Bolivia and Mexico, assuming that Mexico's actual:standard ratio is the same as Bolivia's. §Average of Bolivia and Mexico. Notes: For Bolivia, the original costs were in percapita terms; the South American population and number of hospitalized postabortion cases were used to convert costs to a per-case basis. The Ghana study did not indicate the proportions of cases treated in health centers and hospitals, so an equal distribution was assumed. The Nigerian study used postabortion costs only. $\mathrm{u}=$ unavailable. na=not applicable.

work. ${ }^{22,37}$ Many of these studies investigated operational aspects of the manual vacuum aspiration technique, and excluded patients with severe postabortion complications. The remaining 26 samples included women in all severity categories. The average cost per patient for treating lowseverity complications was $\$ 72$, while the average cost for samples of women with all types of complication was $\$ 111$.

Because a few studies contributed many samples, thus possibly biasing the calculations, averages were recalculated by first determining within-study averages. Then simple averages of these 20 averages were obtained (one study reported two averages, one for each major region). Using this method, the overall average increased slightly to $\$ 88$, while the average for low-severity samples decreased to $\$ 68$ and the all-severity average declined to $\$ 109$. The averages obtained from the two calculation methods were similar, and we used the within-study figures to generate the remaining Table 1 averages.

Of the 20 studies, 10 examined costs in Africa (nine in Sub-Saharan Africa) and 11 in Latin America. * Costs varied little by region, ranging from $\$ 83$ in Africa to $\$ 94$ in Latin America; the average for Sub-Saharan Africa was $\$ 89$. Even though the cost per patient in U.S. dollars was highest in Latin America, after conversion to international dollars, the average costs in Sub-Saharan Africa and in Africa as a whole were substantially higher ( $\$ 228$ and $\$ 213$ vs. $\$ 161$ ). This demonstrates that in relation to patients' purchasing power, abortion complications are considerably more expensive to treat in Africa than in Latin America.

The three cost estimation methods yielded a range of cost-per-case averages. Estimate 1, representing the lower bound of treating only low-severity cases, generated an average cost of \$68. Using Estimate 2-which factored in the pattern of severity of postabortion complications-the cost per case rose to $\$ 115$. Finally, Estimate 3 included over-

*These studies were conducted in six countries in Latin America (Bolivia, Brazil, Ecuador, El Salvador, Mexico and Peru) and eight in Africa (Egypt, Ghana, Kenya, Malawi, Nigeria, South Africa, Tanzania and Uganda).Some countries were included in several studies. head and capital costs, and yielded averages of $\$ 114$ for Africa and \$130 for Latin America. Although limited data prevented more sophisticated estimates, we speculate that if severity patterns and overhead and capital costs could be simultaneously accounted for, cost estimates would be even higher.

The overall costs of postabortion care per patient using the WHO Mother-Baby Package model showed considerable variability across the five countries, from $\$ 10$ to $\$ 112$ (in 2006 US\$) for actual practice, and from $\$ 31$ to $\$ 212$ for care based on WHO standards (Table 2). Costs in Latin America were substantially higher than those in SubSaharan Africa-\$109 vs. \$57 for actual practice, and \$172 vs. $\$ 65$ for WHO-recommended care-primarily reflecting higher Latin American salaries. Except for the Ghana study, a country's WHO standard cost was much higher than its actual cost. This may demonstrate that actual treatment regimes use fewer or lower-quality resources than recommended by the WHO treatment protocols.

\section{Health System Costs}

Based on the top-down approach, estimates of the annual health care system costs of postabortion care in Africa and Latin America combined were $\$ 187$ million (Estimate 1), $\$ 319$ million (Estimate 2) and \$333 million (Estimate 3); the average estimate was $\$ 280$ million (Table 3). The three estimates for Africa ranged from \$117 million to \$199 mil-

\begin{tabular}{|c|c|c|c|c|c|}
\hline Region & $\begin{array}{l}\text { No. of cases } \\
\text { treated } \\
\text { (in 000s) }\end{array}$ & $\begin{array}{l}\text { Estimate } 1 \\
\text { (in 000,000s) }\end{array}$ & $\begin{array}{l}\text { Estimate } 2 \\
\text { (in 000,000s) }\end{array}$ & $\begin{array}{l}\text { Estimate } 3 \\
\text { (in 000,000s) }\end{array}$ & $\begin{array}{l}\text { Average } \\
\text { (in 000,000s) }\end{array}$ \\
\hline Africa & 1,730 & $\$ 117$ & $\$ 199$ & $\$ 198$ & $\$ 171$ \\
\hline Sub-Saharan Africa & 1,180 & $\$ 80$ & $\$ 136$ & $\$ 145$ & $\$ 120$ \\
\hline Latin America & 1,040 & $\$ 70$ & $\$ 120$ & $\$ 135$ & $\$ 108$ \\
\hline Total & 2,770 & $\$ 187$ & $\$ 319$ & $\$ 333$ & $\$ 280$ \\
\hline
\end{tabular}

Notes:Totals include figures for Africa and Latin America. Because of rounding, the average regional costs do not total \$280 million. 


\begin{tabular}{|c|c|c|c|c|c|c|c|}
\hline \multirow[t]{2}{*}{ Region } & \multirow{2}{*}{$\begin{array}{l}\text { No. of } \\
\text { cases } \\
\text { treated } \\
\text { (in 000s) }\end{array}$} & \multicolumn{2}{|c|}{$\begin{array}{l}\text { Cost } \\
\text { (in 000,000s) }\end{array}$} & \multicolumn{2}{|c|}{$\begin{array}{l}\text { Minimum } \\
\text { sensitivity estimate } \\
\text { (in 000,000s) }\end{array}$} & \multicolumn{2}{|c|}{$\begin{array}{l}\text { Maximum } \\
\text { sensitivity estimate } \\
\text { (in 000,000s) }\end{array}$} \\
\hline & & Actual & WHO & Actual & WHO & Actual & WHO \\
\hline Africa & 1,730 & $\$ 114$ & $\$ 141$ & $\$ 99$ & $\$ 112$ & $\$ 188$ & $\$ 298$ \\
\hline Sub-Saharan Africa & 1,180 & $\$ 68$ & $\$ 76$ & $\$ 68$ & $\$ 76$ & $\$ 128$ & $\$ 203$ \\
\hline Latin America & 1,040 & $\$ 113$ & $\$ 179$ & $\$ 60$ & $\$ 67$ & $\$ 113$ & $\$ 179$ \\
\hline Total & 2,770 & $\$ 227$ & $\$ 320$ & $\$ 159$ & $\$ 179$ & $\$ 302$ & $\$ 476$ \\
\hline
\end{tabular}

Notes: Totals include figures for Africa and Latin America. Because of rounding, the maximum sensitivity estimates do not add up to their totals. of reporting of all cost components. Given this imprecision, we also considered cost estimates based on the WHO Mother-Baby Package model. These estimates may more accurately reflect the aggregate costs of postabortion care than the cost-per-case estimates, but because they include all components of treatment cost, they also have weaknesses. In particular, they are derived from a model of postabortion care that has been tested in only five countries. Furthermore, their costs likely reflect the higher standard of care recommended by WHO as compared with what is available and feasible in practice.

This study could not assess the cost of postabortion care in Asia or the developed world because no empirical data were available. In countries where abortion or menstrual regulation is both legal and accessible-such as Bangladesh and Vietnam, as well as some European countries-data on the cost of safe abortion services were available, but these costs were not equivalent to those of postabortion care.

If we apply our lower boundary figure of $\$ 68$ per case, which assumes that all women seeking postabortion care have low-severity complications, to the annual number of cases treated in developing countries in Asia and the Pacific region $(2,280,000),{ }^{2}$ a very approximate minimum estimate of the cost of such care in this region would be \$154 million per year. Adding this to the corresponding figure for Africa and Latin America ( $\$ 187$ million) yields a minimum annual estimate of $\$ 341$ million for postabortion care in the developing world.

Clearly, more costing research is needed, particularly in Asia, where the estimated number of hospitalized postabortion patients is large. In addition, studies are needed to measure the impact of newer methods of abortion (particularly medication abortion), because these methods can reduce the severity of complications of unsafe abortion, and over time will likely reduce the numbers of women who need hospitalization. ${ }^{2}$

As illustrated in Figure 1, the health care system cost of treating serious abortion complications is only one component of the total economic impact on society of unsafe abortion. The costs of treating long-term health consequences, such as chronic pelvic infections and infertility, have hardly been studied. The indirect economic costs of unsafe abortion-those borne by households, by sectors outside the health care system and by the wider economyare also essentially unmeasured. Studies of maternal health have shown that despite the difficulties in measuring the value of women's time in the informal sector, or the home, these costs can be significant. For instance, a study using the REDUCE model estimated that the productivity loss from a maternal death was between $\$ 850$ and $\$ 1,838$ per case (in 2001 U.S. dollars), and the loss related to maternal disability ranged from $\$ 83$ to $\$ 628$ per case. ${ }^{* 38} \mathrm{~A}$ study of how improved vaccination coverage affects productivity estimated that per capita GDP increases by $0.12 \%$ for every 1,000 surviving adults, based on the findings that average wages rise by $0.18 \%$ for every 1,000 peo- 
ple surviving from age 15 to 60 and that labor productivity and wages account for two-thirds of national income. ${ }^{39}$ More evidence of the adverse economic impact of health conditions was found in a study of malaria: The condition accounts for a reduction of $0.25-1.3$ percentage points of economic growth per person per year in malaria-endemic countries, after controlling for demographic and economic factors. ${ }^{40}$ Further research is needed on how the health consequences of unsafe abortion affect women's productivity in low-income settings.

In many low-income countries, households finance a large proportion of health care costs. For example, in SubSaharan Africa, private expenditures represent $60 \%$ of total health care costs. ${ }^{33}$ Therefore, households are likely to bear a substantial proportion of the direct costs of both getting an abortion and treating subsequent complications. Given the controversial nature of abortion as a medical procedure, especially in settings where abortion is illegal, women may find it particularly difficult to access funds from their usual social networks. Indeed, evidence suggests that women are more likely to seek abortion care alone. ${ }^{41}$ For poor households, such expenditures may exacerbate their poverty. ${ }^{42}$ Further research into the household costs of abortion care and coping strategies for paying for care is required.

Many women who need hospital-based care for postabortion complications do not receive it (an estimated $15-25 \%$ of all women who have unsafe abortions). ${ }^{2}$ If they were to receive such care, the cost of unsafe abortion to health care systems would possibly double-and this is likely a minimum estimate of the marginal costs of addressing unmet need for postabortion care. In many settings, there is no capacity to treat these extra cases, implying that additional costs for infrastructure and training would be required. More empirical research into the extent and pattern of unmet need for such care is a priority if the overall economic impact of unsafe abortion is to be better understood.

Unsafe abortions are direct consequences of unwanted pregnancies. The costs we have been able to calculate result from the failure to prevent these pregnancies or, where legal, to terminate them safely. A recent study in Nigeria ${ }^{10}$ estimated that the cost of contraceptive services to prevent unwanted pregnancies would have been only one-fourth of that expended in treating postabortion complications. Another study ${ }^{21}$ showed that the cost of obtaining a safe abortion in Uganda was between $\$ 6$ and $\$ 23$, compared to the average cost of $\$ 89$ that we calculated for treating a postabortion complication in Sub-Saharan Africa. Furthermore, a global study on the costs and benefits of reducing unmet need for contraception estimated that, in Sub-Saharan Africa in 2003, eliminating this unmet need would have cost about US $\$ 1$ billion for additional contraceptive services, while averting 10.5 million unintended

*The authors derived this figure using the United Nations Population Fund's Reproductive Health Costing Tool (<http://www.who.int/pmnch/ topics/economics/costing_tools/en/index15.html >). pregnancies, 3.9 million induced abortions and 23,000 abortion-related deaths. ${ }^{43}$

\section{Conclusions}

Empirical studies of the cost of abortion-related morbidity and mortality are scarce, and existing data are flawed. This study found that the health system costs of postabortion care in Africa and Latin America ranged from \$159 million to $\$ 476$ million per year, depending on the estimation method used. The average estimates from the two approaches largely coincide: $\$ 280$ million using the topdown approach, and $\$ 274$ million using the bottom-up approach (averaging actual and standard practice estimates).

These sums are considerable and impose an added burden on the already overstretched health resources of developing countries. A new United Nations estimate of maternal and newborn health expenditures places the cost of unsafe abortion in context: ${ }^{44}$ Obstetric complications cost health care systems in Africa and Latin America around $\$ 490$ million annually. Thus, treating the serious complications of unsafe abortion represents a financial burden equal to more than half of what is currently spent on obstetric emergencies.

A fuller understanding of the costs of postabortion care is hindered by critical data gaps. We have identified five areas in which additional research is required: the size and characteristics of the large group of women who suffer serious complications but do not receive treatment in the health care system; the economic consequences of morbidity resulting from unsafe abortion, including associated productivity losses; the costs of postabortion care in Asian and Pacific developing countries; the household expenditures for postabortion care and coping strategies for paying; and the impact of newer methods of abortion (particularly medication abortion) on the severity of complications from unsafe abortion.

This study strengthens arguments that unsafe abortion needs to be eliminated. Information on the direct health care system costs of unsafe abortion should be communicated to governments and compared with the much less costly alternatives for preventing unintended pregnancy and unsafe abortion-namely, the provision of contraceptive services and access to safe abortion where it is legal.

\section{REFERENCES}

1. World Health Organization (WHO), Unsafe Abortion: Global and Regional Estimates of the Incidence of Unsafe Abortion and Associated Mortality in 2003, fifth ed., Geneva: WHO, 2007.

2. Singh S, Hospital admissions resulting from unsafe abortion: estimates from 13 developing countries, Lancet, 2006, 368(9550):18871892.

3. Borghi J et al., The financial implications of skilled attendance at delivery: the case of Nepal, Tropical Medicine $\&$ International Health, 2006, 11(2):228-237.

4. Borghi J et al., Mobilising financial resources for maternal health, Lancet, 2006, 368(9545):1457-1465.

5. Strong MA, The health of adults in the developing worlds: the view from Bangladesh, Health Transition Review, 1992, 2(2):215-224.

6. Hutubessy RC et al., Indirect costs of back pain in the Netherlands: 
a comparison of the human capital method with the friction cost method, Pain, 1999, 80(1-2):201-207.

7. McKinlay RJ et al., Optimal search strategies for detecting cost and economic studies in EMBASE, BMC Health Services Research, 2006, Vol. 6, Art. 67, <http://www.biomedcentral.com/1472-6963/6/67>, accessed Aug. 12, 2009

8. Centre for Reviews and Dissemination, University of York, How are studies identified for inclusion into NHS EED? <http://www.york.ac.

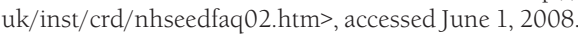

9. Asante FA, Avotri TS and d'Almeida SA, Costing of Safe Motherhood (Making Pregnancy Safer) Initiative in Ghana: A Case Study of Wassa West District, Harare, Zimbabwe: Regional Office for Africa, WHO, 2004.

10. Bankole A et al., Estimating the cost of post-abortion care in Nigeria: a case study, in: Lule E, Singh S and Chowdhury SA, eds., Fertility regulation behaviors and their costs: Contraception and unintended pregnancies in Africa and Eastern Europe \& Central Asia, Health, Nutrition, and Population Discussion Paper, Washington, DC: World Bank, 2007, pp. 65-92.

11. Benson J and Huapaya V, Sustainability of Postabortion Care in Peru, Washington, DC: Frontiers in Reproductive Health, Population Council, 2002

12. Billings DL, Del Pozo E and Arévalo H, Testing a model for the delivery of emergency obstetric care and family planning services in the Bolivian public health system, Washington, DC: Frontiers in Reproductive Health, Population Council, 2003.

13. Brambila $C$ et al., Estimating costs of postabortion services at Dr. Aurelio Valdivieso General Hospital, Oaxaca, Mexico, in: Huntington D and Piet-Pelon NJ, eds., Postabortion Care: Lessons from Operations Research, New York: Population Council, 1999, pp. 108-124.

14. Cahuana-Hurtado L, Sosa-Rubi S and Bertozzi S, Costo de la atención materno infantile en el estado de Morelos, México, Salud Pública de México, 2004, 46(4):316-325.

15. Capra K et al., MotherCare Bolivia-cost study of the Mother-Baby Package in Bolivia, MotherCare Matters, 2000, 9(1):5-8

16. Fonseca $\mathrm{W}$ et al., Adoption of manual vacuum aspiration for treatment of incomplete abortion reduces costs and duration of patient's hospital stay in an urban area of northeastern Brazil, Revista de Saúde Pública, 1997, 31(5):472-478 (in Portuguese).

17. Guzman A, Ferrando D and Tuesta L, Treatment of incomplete abortion: manual vacuum aspiration versus curettage in the Maternal Perinatal Institute in Lima, Peru, Working Paper, Boston, MA, USA: Pathfinder International, 1995

18. John Snow International, Cost of the Mother-Baby Package in Bolivia, Technical Working Paper, Cambridge, MA, USA: John Snow Inc., 1999, No. 11

19. Johnson BR et al., Costs of alternative treatments for incomplete abortion, Policy Research Working Papers, Washington, DC: World Bank, 1993, No. 1072.

20. Johnson BR et al., Costs and resource utilization for the treatment of incomplete abortion in Kenya and Mexico, Social Science $\&$ Medicine, 1993, 36(11):1443-1453.

21. Johnston HB, Gallo MF and Benson J, Reducing the costs to health systems of unsafe abortion: a comparison of four strategies, Journal of Family Planning and Reproductive Health Care, 2007, 33(4):250-257.

22. Kay BJ et al., An analysis of the cost of incomplete abortion to the public health sector in South Africa-1994, South African Medical Journal, 1997, 87(4):442-447.

23. King TDN, Benson J and Stein K, Comparing the cost of postabortion care in Africa and Latin America, in: The DataPAC Project, Global Meeting on Post-abortion Care: Advances and Challenges, New York: Population Council, 1998.

24. Konje JC, Obisesan KA and Ladipo OA, Health and economic consequences of septic induced abortion, International Journal of Gynecology \& Obstetrics, 1992, 37(3):193-197.

25. Koontz SL et al., Treating incomplete abortion in El Salvador: cost savings with manual vacuum aspiration, Contraception, 2003, 68(5):
345-351.

26. Levin A et al., Costs of maternal health care services in three anglophone African countries, International Journal of Health Planning and Management, 2003, 18(1):3-22.

27. Magotti RF et al., Cost-effectiveness of managing abortions: manual vacuum aspiration (MVA) compared to evacuation by curettage in Tanzania, East Africa Medical Journal, 1995, 72(4):248-251.

28. Nawar L, Huntington D and Abdel Fattah MN, Cost analysis of postabortion service in Egypt, in: Huntington D and Piet-Pelon NJ, eds., Postabortion Care: Lessons from Operations Research, New York: Population Council, 1999

29. Levin C et al., Exploring the costs and economic consequences of unsafe abortion in Mexico City before legalisation, Reproductive Health Matters, 2009, 17(33):120-132.

30. Rogers $\mathrm{P}, \mathrm{A}$ cost-benefit analysis of first trimester abortion proce dures with manual vacuum aspiration and uterine curettage at Municipal Hospital Dr. Arthur Ribeiro de Saboya, Sao Paulo, Brazil, Working Paper, Chapel Hill, NC, USA: Ipas, 1995.

31. Weissman E et al., Uganda Safe Motherhood Programme: Costing Study, Geneva: WHO, 1999

32. Kumaranayake L, The real and the nominal? making inflationary adjustments to cost and other economic data, Health Policy and Planning, 2000, 15(2):230-234

33. World Bank, World Development Indicators, 2009, <http://www worldbank.org/data/>, accessed Aug. 25, 2009.

34. Gebreselassie $\mathrm{H}$ et al., The magnitude of abortion complications in Kenya, British Journal of Obstetrics and Gynaecology, 2005, 112(9): 1229-1235

35. WHO, Mother-Baby Package Costing Spreadsheet: User Guide, Version 1.01, Geneva: WHO, 1999.

36. WHO, Mother-Baby Package: Implementing Safe Motherhood in Countries, Geneva: WHO, 1994

37. Rees $\mathrm{H}$ et al., The epidemiology of incomplete abortion in South Africa, South African Medical Journal, 1997, 87(4):432-437.

38. Islam MK and Gerdtham UG, The costs of maternal-newborn illness and mortality, in: Moving Towards Universal Coverage: Issues in Maternal and Newborn Health and Poverty, Geneva: WHO, 2006.

39. Bloom D, Canning D and Wilson $\mathrm{M}$, The value of vaccination, World Economics, 2005, 6(3):15-39.

40. Gallup JL and Sachs JD, The economic burden of malaria, American Journal of Tropical Medicine and Hygiene, 2001, 64(1 Suppl.):85-96.

41. Bowes T and Macleod C, The characteristics of women seeking termination of pregnancy at an urban-based government hospital in the Eastern Cape, Curationis, 2006, 29(4):12-18

42. Storeng KT et al., Paying the price: the cost and consequences of emergency obstetric care in Burkina Faso, Social Science $\&$ Medicine, 2008, 66(3):545-557.

43. Vlassoff $\mathrm{M}$ et al., Assessing costs and benefits of sexual and reproductive health interventions, Occasional Report, New York: The Alan Guttmacher Institute, 2004, No. 11.

44. United Nations Economic and Social Council, Flow of financial resources for assisting in the implementation of the Programme of Action of the International Conference on Population and Development, Conference Room Paper, New York: United Nations, 2009

\section{RESUMEN}

Contexto: Cada año ocurren 19 millones de abortos inseguros en los países en desarrollo y se estima que cinco millones de mujeres reciben tratamiento por complicaciones médicas graves resultantes. Entretanto, es poco lo que se conoce sobre el impacto económico de la atención postaborto en los sistemas de salud en África y América Latina (en Asia no hay estudios) 
Métodos: Dos enfoques principales fueron utilizados para estimar el costo de la atención postaborto: calcular el costo promedio de atención por paciente, como se describe en 20 estudios empíricos; y analizar los costos de tratamiento con el modelo de Paquete Madre-Bebé de la OMS, el cual enumera los costos de componentes específicos de tratamiento relacionados con las complicaciones postaborto. Las estimaciones de costo promedio de cada enfoque se multiplicaron por el número anual de casos de hospitalización por atención postaborto para generar estimaciones regionales de costo. Tres métodos (severidad baja, severidad ponderada e inclusión de costos administrativos y de capital) fueron usados para generar una gama de estimaciones de costo por paciente y por región.

Resultados: El costo promedio de la atención postaborto por paciente. en US dólares de 2006, varió de \$83 en África a \$94 en América Latina; las estimaciones basadas en el modelo de Paquete Madre-Bebé de la OMS fueron entre \$57 y \$109 por caso. Los costos de la atención postaborto para el sistema de salud en las dos regiones combinadas variaron entre \$159 millones y \$333 millones por año. Las estimaciones centrales de los dos enfoques fueron similares: $\$ 280$ millones y $\$ 274$ millones, respectivamente.

Conclusiones: Los costos del tratamiento de las complicaciones médicas derivadas del aborto inseguro constituyen una significativa carga financiera para los sistemas de salud pública en el mundo en desarrollo; $y$ las complicaciones postaborto son una causa significativa de morbilidad materna.

\section{RÉSUMÉ}

Contexte: Chaque année, 19 millions d'avortements non médicalisés sont pratiqués dans le monde en développement et on estime à cinq millions le nombre de femmes traitées pour les complications médicales graves qui en résultent. L'impact éco- nomique des soins après avortement sur les systèmes de soins de santé d'Afrique et d'Amérique latine est cependant mal compris (aucune étude n'est disponible pour l'Asie).

Méthodes: Deux grandes approches ont été adoptées pour estimer le coût des soins après avortement: le calcul du coût moyen des soins par patiente, tel que représenté dans 20 études empiriques, et l'analyse des coûts de traitement selon le modèle du Dossier mère-enfant de l'OMS, qui énumère les coûts des composants spécifiques du traitement des complications de l'avortement. Les estimations de coûts moyens obtenues de chaque approche ont été multipliées par le nombre annuel de cas d'hospitalisation pour soins après avortement dans le but de produire des estimations de coûts régionales. Trois méthodes (faible gravité, gravité pondérée et inclusion des frais généraux et coûts en capital) ont été utilisées pour générer une plage d'estimations des coûts par patiente et régionaux.

Résultats: Le coût moyen par patiente des soins après avortement varie entre 83 dollars en Afrique et 94 dollars en Amérique latine (en dollars américains de 2006). Les estimations basées sur le modèle du Dossier mère-enfant de l'OMS varient entre 57 et 109 dollars par cas. La charge sanitaire des soins après avortement dans les deux régions combinées varie entre 159 et 333 millions de dollars par an. Les deux approches produisent des estimations centrales similaires: 280 millions et 274 millions de dollars, respectivement.

Conclusions: Les coûts du traitement des complications médicales de l'avortement non médicalisé représentent une charge financière considérable pour les systèmes de soins de santé publique du monde en développement. Les complications de l'avortement représentent en outre une cause significative de morbidité maternelle.

Author contact: mvlassoff@guttmacher.org 